Jurnal Aplikasi IPTEK Indonesia

ISSN Print: 2614-2465 - ISSN Online: 2614-2473

Universitas Negeri Padang

http://bk.ppj.unp.ac.id/index.php/aiptekin/index

\title{
Pelatihan Pemanfaatan Program Analisis Sosiometri dalam Pelayanan Bimbingan dan Konseling bagi Konselor
}

\author{
Yusri Yusri ${ }^{1}$ Frischa Meivilona Yendi ${ }^{2}$ \\ ${ }^{12}$ Universitas Negeri Padang \\ *Corresponding author, e-mail: yusri@konselor.org
}

\begin{abstract}
To improve the educational quality is an importan attemp that should be done by all Indonesian and government. The bundles of educational problems have to be solved and distributed not only to the municipal government but also to the prefectural government and the stakeholders of education. The distribution of task and responbility on the improvement of educational quality cannot be done automatically without stakeholders' comprehension and understanding of the importance of educational improvement. But, teachers and school principal at least can do much when the stakeholdersgive much attention and prosperity to make them better life and more professional. In addition, the concept of school based management should be implemented soon to support the decentralization of educational management. It hopefully could make more effective beurocracy. However, it has to be implement wisely and carefully to avoid wider corruption, collusion, and nepotism at the local and root level.
\end{abstract}

Keywords: Quality of Educational, teacher profesionalism, school's based management.
Received October 29, 2017;

Revised November 22, 2017;

Accepted December 25, 2017;

Published Online January, 2018

Conflict of Interest Disclosures:

The authors declare that they have no significant competing financial, professional or personal interests that might have influenced the performance or presentation of the work described in this manuscript.

How to Cite: Yusri Y \& Yendi, F., M. (2017). Pelatihan Pemanfaatan Program Analisis Sosiometri dalam Pelayanan Bimbingan dan Konseling bagi Konselor. Jurnal Aplikasi IPTEK Indonesia, 1(1), 1-5. DOI: 10.24036/4.115

\section{Pendahuluan}

Dalam dunia konseling saat ini berkembang istilah e-counseling (electronic counseling) yang diartikan sebagai proses penyelenggaraan konseling secara elektronik. Ifdil (2012) menyatakan pelayanan e-counseling tidak hanya terbatas pada penyelenggaraan konseling individual saja, namun diperluas menjadi penyelenggaraan BK secara keseluruhan. Tidak hanya konseling melalui internet, namun juga semua aspek pemanfaatan teknologi informasi dan komunikasi dalam penyenggaraan BK, seperti penggunaan dan pemanfaatan program instrumentasi, himpunan data siswa, aplikasi manajemen konseling, pemanfaatan media saat pemberian layanan format klasikal, dan sebagainya, termasuk juga pemanfaatan telepon untuk penyelenggaraan konseling.

Sejak lahirnya istilah pelayanan e-konseling, telah banyak dikembangkan berbagai aplikasi penunjang penyelenggaraan BK di Indonesia seperti Program Aplikasi untuk pengolahan Alat Ungkap Masalah (AUM), Program Analisis Tugas Perkembangan (ATP), Program Daftar Cek Masalah (DCM), Program Aplikasi IKMS, Database Siswa, termasuk Program Aplikasi E-sosiometri, dan sebagainya. 
Hasil aplikasi instrumentasi pada hakekatnya dapat diaplikasikan dalam seluruh spektrum kegiatan pelayanan konseling, mulai dari perencanaan sampai dengan penilaian dan pengembangannya. Bahkan memungkinkan kegiatan aplikasi instrumentasi ini merupakan langkah yang menentukan dalam penentuan pemberian layanan konseling (Mastur. 2010).

Seiring dengan sudah banyaknya software dan aplikasi pendukung yang beredar dan semakin berkembangnya teknologi informasi, kondisi ini mengharuskan para guru BK/konselor untuk menguasainya. Lebih lanjut, menurut Ifdil (dalam Syamsu Yusuf LN. 2011) jika tidak dikuasai kondisi BK kita akan kian terpuruk, guru BK/konselor dipandang gagap teknologi, guru BK/konselor dipandang terlalu rigit dan tidak mau berkembang. Meskipun kondisi di lapangan saat ini memperlihatkan kondisi yang sangat memprihatinkan. Masih ada guru BK/konselor yang belum mengenal internet, tidak memiliki alamat email, tidak memanfaatkan fasilitas teknologi informasi yang disediakan sekolah, bahkan masih ada guru BK/konselor yang belum bisa menggunakan komputer sama sekali untuk keperluan yang sederhana, dalam menunjang penyelenggaraan tugasnya (Bariyyah \& Permatasari, 2017; Ifdil \& Ardi, 2013).

Penentuan materi dan metode pelaksanaan ditentukan berdasarkan studi awal. Studi awal yang dilakukan di Kabupaten Tanah Datar, menemukan fenomena bahwa masih ada guru BK/konselor yang belum memanfaatkan teknologi dalam upaya membantu proses pemberian pelayanan konseling secara garis besar. Indikator ini terlihat dengan rendahnya tingkat pemahaman dan pemanfaat komputer secara umum oleh guru $\mathrm{BK} /$ konselor dalam membantu menjalankan tugas, pengetahuan dan pemahaman guru BK/konselor tentang instrumentasi, khususnya pengolahan sosiometri belum optimal.

Sosiometri merupakan sebuah metode yang diciptakan oleh Jacob Moreno Levy dalam studi tentang hubungan antara struktur sosial dan kesejahteraan psikologis (Harum, 2015; Purnomo, Pangarsa, Andri, \& Saeri, 2017). Sosiometri bertujuan untuk mempelajari struktur kelompok dari hubungan interpersonal yang terjadi di dalamnya (Moreno, 1961, Lambert M. S.; 2010, Ballesteros-Pérez, etc; 2012).

Lebih lanjut, Eko Susanto (2012) mengemukakan sosiometri merupakan salah satu prosedur non tes yang dapat digunakan oleh guru BK/konselor untuk mengetahui dinamika hubungan sosial siswa di kelas. Hal ini penting dilakukan untuk mengetahui suasana kelas yang dapat mendukung dalam pengembangan kehidupan efektif sehari-hari (KES) siswa. Data hasil analisis sosiometri juga dapat digunakan oleh guru BK/konselor dalam merencakan kegiatan layanan BK yang tepat sasaran (Kusuma \& Budiyanto, 2015).

Dengan menggunakan program aplikasi diharapkan dapat meringankan tugas konselor/guru BK khususnya dalam melakukan studi kebutuhan (need assessment) yang menjadi dasar pertimbangan dalam perencanaan pelayanan konseling (Ardi, Yendi, \& Ifdil, 2013). Selain itu, bagi pelaksana kegiatan ini merupakan penyelenggaraan salah satu aspek Tri Dharma Perguruan Tinggi, yaitu melakukan kegiatan pengabdian kepada masyarakat.

\section{Metodologi}

Metode yang digunakan dalam kegiatan pelatihan kali ini adalah ceramah (Harsono, 2009), yakni peneliti menyampaikan informasi dan materi berkenaan degan sosiometri, Tanya jawab (Saleh, 2017) dilakukan untuk memberikan kesempatan kepada peserta menanyakan berbagai hal yang belum dimengerti dan dipahami, serta metode latihan (Lestari, Wujoso, \& Suryani, 2017) untuk melatih para peserta menggunakan aplikasi guna meningkatkan keterampilan guru BK/Konselor dalam menyelenggarakan layanan-layanannya.

\section{Hasil}

Dari evaluai hasil pelatihan yang dilakukan dapat disimpulkan bahwa peserta telah mendapatkan wawasan dan pengetahuan dalam pemanfaatan teknologi dalam BK secara umum. Guru BK/konselor telah memiliki wawasan baru bahwa pengolahan sosiometri dapat dilakukan dengan bantuan komputer, dengan menggunakan

Jurnal Aplikasi IPTEK Indonesia, Open Access: http://bk.ppj.unp.ac.id/index.php/aiptekin/index 
Jurnal Aplikasi IPTEK Indonesia

ISSN Print: 2614-2465 - ISSN Online: 2614-2473

e-sosiometri. Setelah mengikuti kegiatan pelatihan ini, guru BK/konselor di Batusangkar merasa sangat berterimakasih karena telah mendapatkan wawasan, berbagi ilmu dan pengetahuan, pemahaman dan keterampilan dalam menunjang penyelenggaraan tugas sebagai guru BK/konselor di sekolah, selain itu pelatihan ini telah membawa nuansa baru dalam dunia konseling setempat, kegiatan ini memberikan semangat kembali kepada para guru BK/konselor untuk lebih giat lagi, bahkan harapan ini dikemukakan langsung oleh perwakilan dari peserta agar kegiatan serupa lebih sering untuk dilaksanakan. Lebih lanjut disampaikan agar setiap tahunnya peserta meminta agar senantiasa dilakukan pelatihan dan kerjasama antar UNP sebagai pelaksana dan Musyawarah Guru Bimbingan dan Konseling (MGBK) sebagai wadah perkumpulan guru BK/konselor, saling bersinergi untuk mengaplikasikan ilmu menuju optimalisasi potensi peserta didik di lapangan, menjawab permasalahan-permasalahan kualitas maupun manajemen pendidikan dalam rangka otonomi daerah dan otonomi pendidikan di masa yang akan datang.

\section{Pembahasan}

Guru BK/konselor dituntut untuk ikut berperan serta dan menguasai teknologi informasi dewasa ini. Penguasaan teknologi dimaksudkan dalam rangka untuk menjalankan tugas secara optimal, baik itu pada setting sekolah dan di luar sekolah. Guru BK/konselor benar-benar dituntut untuk memiliki wawasan, pengetahuan, keterampilan, nilai dan sikap. Selain itu juga dibutuhkan sarana dan prasana, seperti ketersediaan ruang konseling, buku-buku, media visual seperti rekaman konseling, video layanan dan pemunculan programprogram aplikasi inventori dan instrumen serta yang lainnya yang pada intinya untuk membantu para guru $\mathrm{BK} /$ konselor dalam menjalankan tugasnya.

Hadirnya program aplikasi dalam BK merupakan terobosan baru dalam bidang ini, misalnya munculnya istilah pelayanan e-konseling. Wujud nyata aplikasi dari e-konseling adalah dengan bermunculannya pelayanan konseling secara online, melalui situs-situs penyedia layanan konseling online, atau yang lebih sederhana konseling yang dilakukan melalui telepon, handphone dan/atau melalui email pribadi dan beberapa program aplikasi untuk chatting seperti skype, yahoo mesengger dan sebagainya. Namun, kenyataan selama ini menunjukkan bahwa sebagian besar guru BK/konselor belum mampu mengoptimalkan penggunaan teknologi informasi tersebut. Kondisi ini bisa ditingkatkan dengan kerjasama yang baik antara perguruan tinggi dengan para penyenggara BK di lapangan. Salah satunya melalui kegiatan seperti yang dilakukan ini, yaitu melatih guru $\mathrm{BK} /$ konselor untuk mengoptimalkan pemanfaatan teknologi informasi dalam pelayanan konseling terutama pemanfaatan e-sosiometri sebagai salah satu inventori yang bisa digunakan oleh guru BK/konselor di sekolah.

Aplikasi e-sosiometri dikembangkan oleh Eko Susanto pada Tahun 2011 dan secara berkala mulai direvisi dan diperbaiki. Pengembangan berbagai aplikasi bertujuan untuk membantu kinerja para penyelenggara BK di lapangan. Salah satunya adalah aplikasi ini yang dapat digunakan untuk mengolah data sosiometri yang juga dilengkapi dengan instrumen sosiometrinya (Ifdil, 2012a). Aplikasi ini memudahkan para guru BK/konselor untuk mengaplikasikan sosiometri di sekolah, mulai dari membuat lembar instrumen sosiometri, mengolah, mencetak, hingga menjadi himpunan data yang dapat membantu para guru BK/konselor melakukan pelayanan BK di sekolah.

\section{Kesimpulan}

Pelatihan pemanfaatan program analisis sosiometri dalam pelayanan bimbingan dan konseling bagi guru BK/Konselor dapat mempermudah kinerja guru BK/Konselor dalam melakukan studi kebutuhan (need assessment) yang bias menunjang guru BK/Konselor dalam menjalankan layanan-layanannya. Selanjutnya dilakukan analisis jangka pendek dengan mengobservasi hasil penyampaian pesan kesan diperoleh bahwa peserta merasa sangat terbantu dan mengucapkan syukur, serta berharap pelatihan ini bias dilaksanakan juga bagi guru $\mathrm{BK} /$ konselor lainya. 


\section{Referensi}

Ardi, Z., Yendi, F. M., \& Ifdil, I. (2013). Konseling Online: Sebuah Pendekatan Teknologi Dalam Pelayanan Konseling. Jurnal Konseling dan Pendidikan, 1(1), 1-5.

Bariyyah, K., \& Permatasari, D. (2017). Pelatihan Pemanfaatan Media Online Dalam Layanan Bimbingan Konseling Bagi Konselor Sekolah Menengah Pertama Di Kabupaten Pamekasan Madura. Dedication: Jurnal Pengabdian Masyarakat, 1(1), 63-69.

Harsono, B. (2009). Perbedaan Hasil Belajar Antara Metode Ceramah Konvensional dengan Ceramah Berbantuan Media Animasi pada Pembelajaran Kompetensi Perakitan dan Pemasangan Sistem Rem. Jurnal Pendidikan Teknik Mesin, 9(2).

Harsono, B. (2009). Perbedaan Hasil Belajar Antara Metode Ceramah Konvensional dengan Ceramah Berbantuan Media Animasi pada Pembelajaran Kompetensi Perakitan dan Pemasangan Sistem Rem. Jurnal Pendidikan Teknik Mesin, 9(2).

Harum, A. (2015). Pengembangan Program Sosiometri Sebagai Media Pengungkapan Hubungan Sosial Siswa SMAN 9 Makassar. Jurnal Psikologi Pendidikan dan Konseling: Jurnal Kajian Psikologi Pendidikan dan Bimbingan Konseling, 1(2), 105-115.

Ifdil, I. (2010). Pendidikan Karakter dalam Bimbingan dan Konseling. Pedagogi: Jurnal Ilmu Pendidikan, 10(2), 5561.

Ifdil, I., \& Ardi, Z. (2013). Konseling Online Sebagai Salah Satu Bentuk Pelayanan E-konseling. Jurnal Konseling dan Pendidikan, 1(1), 15-22.

Kusuma, I., \& Budiyanto, S. M. (2015). Pengembangan Model Perencanaan Himpunan Data Dan Aplikasi Instrumentasi Berbasis Pola Tujuh Belas Plus Pada Guru Bk/Konselor Smp Di Kabupaten Bondowoso. Jurnal Pendidikan Ilmu Sosial, 25(2), 86-97.

Lestari, T., Wujoso, H., \& Suryani, N. (2017). Pengaruh Metode Pembelajaran Ceramah Plus dan Metode Drill terhadap Motivasi Belajar dan Hasil Belajar pada Kompentensi Dasar Efisiensi penggunaan Tempat Tidur Rumah Sakit. Media Ilmu Keolahragaan Indonesia, 7(1), 16-23.

Lestari, T., Wujoso, H., \& Suryani, N. (2017). Pengaruh Metode Pembelajaran Ceramah Plus dan Metode Drill terhadap Motivasi Belajar dan Hasil Belajar pada Kompentensi Dasar Efisiensi penggunaan Tempat Tidur Rumah Sakit. Media Ilmu Keolahragaan Indonesia, 7(1), 16-23.

Purnomo, E., Pangarsa, N., Andri, K. B., \& Saeri, M. (2017). Efektivitas Metode Penyuluhan Dalam Percepatan Transfer Teknologi Padi Di Jawa Timur. Jurnal Inovasi Dan Teknologi Pembelajaran (JINOTEP), 1(2).

Rochiati, Wiraatmaja. (2005). Metode Penelitian Tindakan Kelas. Untuk meningkatkan kinerja guru dan dosen. Bandung : Kerjasama Pascasarjana UPI dan PT Remaja Rosdakarya.

Saleh, M. (2017). Penerapan Metode Tanya Jawab Dalam Upaya Meningkatan Hasil Belajar Pendidikan Agama Islam. JURNAL PENA EDUKASI, 3(5), 426-433.

Sudarsono, F.X. (1997). Pedoman Pelaksanaan Penelitian Tindakan Kelas: Bagian Kedua, Rencana, Desain dan Implementasi. Yogyakarta : UKMP SD, BP3SD.

Suharsimi Arikunto dkk (2006). Penelitian Tindakan Kelas . Jakarta.PT Bumi Aksa.

Supardi. (2004). Penelitian Tindakan Kelas: Penyusunan Proposal dan Laporan Penelitian. Jakarta : Dirjen Dikdasmen.

Suwarsih, Madya. (1994). Panduan Penelitian Tindakan . Yogyakarta : Lembaga Penelitian IKIP Yogyakarta.

Suyanto. (1997). Pedoman Pelaksanaan Penelitian Tindakan Kelas (PTK).: Bagian kesatu, PengenalanPenelitian Tindakan Kelas.. Yogyakarta UKMP SD, BP3SD.

Jurnal Aplikasi IPTEK Indonesia, Open Access: http://bk.ppj.unp.ac.id/index.php/aiptekin/index 